\title{
Pengaruh Idealisme, Tingkat Pengetahuan dan Love of Money Pada Persepsi Etis Mahasiswa Akuntansi
}

\author{
Ni Luh Eka Prilly Kartika Putri ${ }^{1}$ \\ Fakultas Ekonomi dan Bisnis \\ Universitas Udayana, Indonesia. \\ Email: prillykp@gmail.com
}

\author{
Luh Gede Krisna Dewi² \\ Fakultas Ekonomi dan Bisnis \\ Universitas Udayana, Indonesia.
}

\begin{abstract}
ABSTRAK
Penelitian ini bertujuan untuk mengetahui bagaimana persepsi mahasiswa atas prilaku tidak etis akuntan dengan beberapa variabel yaitu idealisme, tingkat pengetahuan dan love of money.Penelitian ini menggunakan data kuesioner sebagai instrument yang disebar kepada responden. Responden penelitian ini adalah mahasiswa jurusan akuntansi Fakultas Ekonomi dan Bisnis Universitas Udayana angkatan 2015. Jumlah sampel yang digunakan 142 sampel dengan teknik nonprobability sampling. Teknik analisis data yang digunakan adalah analisis regresi linier berganda.Berdasarkan hasil analisis menunjukkan semakin tinggi idealisme dalam memegang prinsip etika maka mahasiswa akan senantiasa berperilaku etis, semakin tinggi tingkat pengetahuan yang dimiliki mahasiswa maka akan lebih etis memberikan tanggapan ataupun masukan dan semakin tinggilove of money, maka usaha untuk melakukan segala cara agar kebutuhan terpenuhi walau tidak sesuai dengan etika.
\end{abstract}

Kata Kunci : Idealisme; Tingkat Pengetahuan; Love Of Money dan Persepsi Etis.

\section{Effects of Idealism, Knowledge Level and Love of Money on Ethical Perceptions of Accounting Students}

\begin{abstract}
This study aims to determine how students 'perceptions of accountants' unethical behavior with several variables, namely idealism, level of knowledge and love of money. This study uses questionnaire data as an instrument distributed to respondents. Respondents of this study were students of the accounting department of the Faculty of Economics and Business, Udayana University class 2015. The number of samples use 142 samples with nonprobability sampling technique. The data analysis technique used is multiple linear regression analysis. Based on the results of the analysis, the higher idealism in holding ethical principles, the students will always behave ethically, the higher level of knowledge possessed by students, the more ethical or responsive input will be and the higher love of money, the effort to do everything so that needs are met not in accordance with ethics.
\end{abstract}

Keywords: Idealism; Level Of Knowledge; Love Of Money and Ethical Perception.

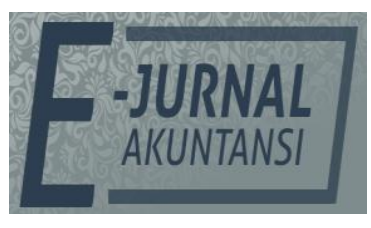

E-JA

e-Jurnal Akuntansi e-ISSN 2302-8556

Vol. 8 No. 2

Denpasar, Oktober

2019

Hal. 32-49

Artikel masuk:

12 Juni 2019

Tanggal diterima:

19 Agustus 2019 


\section{PENDAHULUAN}

Bidang profesi akuntansi pun tidak luput dari pelanggaran dan kecurangan yang menimbulkan krisis etika dan krisis kepercayaan. Krisis kepercayaan ini diketahui karena bannyaknya kasus pelanggaran etika yang menimbulkan krisis kepercayaan. Pada saat ini masih banyak terjadi pelanggaran etika yang dilakukan oleh akuntan yang disebabkan oleh praktik-praktik profesi yang mengabaikan standar akuntansi bahkan etika.

Sebuah skandal dalambidang akuntansi adalah kasus Kantor Akuntan Publik (KAP) Drs. Ketut Gunarsa di Bali yang terletak di Jalan Tukad Banyusari Gg.II No:5 Denpasar. Menteri Keuangan (Menkeu) membekukan izin Akuntan Publik (AP) Drs. Ketut Gunarsa, Pemimpin Rekan dari Kantor Akuntan Publik (KAP) K.Gunarsa dan I.B Djagera selama enam bulan.Sanksi pembekuan izin diberikan karena Akuntan Publik tersebut melakukan pelanggaran terhadap Standar Profesional Akuntan Publik (SPAP) dalam pelaksanaan audit atas laporan keuangan Balihai Resort and Spa untuk tahun buku 2004 yang berpotensi berpengaruh signifikan terhadap Laporan Auditor Independen. Selama izinnya dibekukan, Akuntan Publik dilarang memberikan jasa atestasi termasuk audit umum, review, audit kinerja dan audit khusus serta dilarang menjadi Pemimpin Rekan atau Pemimpin Cabang KAP namun tetap bertanggung jawab atas jasa-jasa yang telah diberikan, serta wajib memenuhi ketentuan mengikuti Pendidikan Profesional Berkelanjutan (PPL). Pembekuan izin oleh Menkeu tersebut sesuai dengan Keputusan Menkeu Nomor 423/KMK.06/2002 tentang Jasa Akuntan Publik sebagaimana telah diubah dengan Keputusan Menkeu Nomor 359/KMK.06/2003(Detik Finance, 2007).

Berdasarkan kasus pelanggaran etik tanpa disadari membentuk suatu reaksi yang menjadi sebuah persepsi dari mahasiswa pada profesi di bidang akuntansi. Persepsi adalah sikap ataupun pendapat yang dicurahkan untuk memberi respon ataupun memberi tafsiran suatu fenomena. Dalam penelitian ini bertujuan untuk mengetahui bagaimana persepsi mahasiswa atas prilaku tidak etis akuntan dan setiap mahasiswa harus memiliki persepsi moral, penalaran serta prilaku yang berbeda-beda, walaupun mereka sudah mengenyam pendidikan etika dengan porsi yang merata (Smith, 2009).

Idealisme merupakan sikap yang menuruti hukum, dalam Kasus KAP Drs. Ketut Gunarsa. Menteri Keuangan memiliki sikap idealisme yang tinggi karena menganggap tindakan baik atau buruk akan membawa konsekuensinya sendiri serta cenderung akan berperilaku menuruti aturan. Sehingga pada kasus KAP Drs. Ketut Gunarsa, dimana Menkeu sudah melaksanakan tugasnya yang sesuai dengan sikap Idealisme yang dimilikinya. Forsyth (1980) menjelaskan idealisme merupakan dimensi yang menggambarkan ideologi etika, individu yang memiliki ideologi etika idealisme maka individu akan menganggap bahwa tindakan baik atau buruk akan membawa konsekuensinya, serta cenderung akan berprilaku sesuai dengan aturan dan prinsip-prinsip moral. Namun, terdapat pendapat yang berbeda penelitian (Nugroho, 2008) yang menyatakan bahwa tingkat idealisme tidak berpengaruh pada persepsi mahasiswa terhadap tindakan auditor, sehingga mahasiswa yang memiliki tingkat idealisme lebih tinggi belum tentu akan menilai pelanggaran tindakan auditor dengan lebih tegas. 
Tingkat Pengetahuan merupakan informasi atau maklumat yang diketahui atau disadari seseorang. Jadi dalam Kasus KAP Drs. Ketut Gunarsa ini, setelah dibekukanya izin dalam melakukan jasa audit, tetapi harus bertanggung jawab atas jasa-jasa yang telah diberikan serta wajib memenuhi kententuan Pendidikan Profesional Berkelanjutan (PPL), sehingga pengetahuan sangat dibutuhkan untuk dapat menilai tindakan yang baik atau buruk yang dapat terjadi dalam melaksanakan tugas seorang akuntan. Tingkat pengetahuan akan mempengaruhi persepsi seseorang tentang etika, seseorang yang mempunyai pengetahuan yang tinggi akan dianggap memiliki etika yang juga tinggi serta penalaran moral yang tinggi. Gadjali \& Birton (2014) menyatakan bahwa mahasiswa akuntansi dengan komitmen professional yang lebih tinggi dan sosialisasi antisipasi lebih mungkin mempertanyakan tindakan tidak etis dibandingkan dengan mahasiswa lain. Sedangkan, untuk variabel tingkat pengetahuan, hasil penelitian (Comunale et al., 2006) menunjukan bahwa tingkat pengetahuan mahasiswa akuntansi terhadap skandal dan profesi akuntansi akan berpengaruh signifikan terhadap pertimbangan etika mahasiswa akuntansi.

Keterlibatan Kasus KAP Drs. Ketut Gunarsa dihubungkan dengan Love of Money yaitu manipulasi laporan keuangan Bali Hai Resort and Spa. Sikap yang dimiliki Pemimpin KAP ini mendeskripsikan sikap Love of Money pada Kasusnya sehingga ia tidak lagi diizinkan dalam melaksanakan jasa audit. Menurut Thomas \& Tang (1992) menguji sebuah variabel psikologis baru yaitu induvidu cinta uang (love of money) menghasilkan sebuah pengukuran yang disebut money ethic scale (MES), yang termasuk di dalamnya adalah sikap positif, sikap negatif, pencapaian, kekuatan, pengelolaan uang, dan penghargaan.

Penelitian Luna \& Tang (2004) menemukan bahwa kesehatan mental professional dengan love of money paling rendah menghasilkan pergantian karyawan paling sedikit walaupun dengan tingkat kepuasan kerja yang rendah. Hubungan yang signifikan antara love of money dan perilaku tidak etis dan memberi label Love of Money merupakan akar dari kejahatan. Penelitian Jwa.K et al., (2000) memberikan hasil yang berbeda. Mereka berpendapat bahwa love of money dapat membantu memprediksi dan mengendalikan perilaku tidak etis. Hal tersebut didasari karena dengan love of money seseorang dapat memprediksi kepuasan kerja dan kemungkinan perilaku tidak etis.

Alasan dalam pemilihan variabel idealisme, tingkat pengetahuan dan love of money, karena idealilsme dan love of money merupakan bagian dari faktor internal atau psikologis individu sedangkan tingkat pengetahuan merupakan faktor eksternal atau kognitif individu. Faktor psikologis merupakan sikap atau tingkah laku yang didorong oleh jiwa atau mental dalam diri sendiri untuk melakukan segala tindakan, sedangkan faktor kognitif secara umum kognitif diartikan potensi intelektual yang terdiri dari tahapan: pengetahuan, pemahaman, penerapan, analisa, sintesa dan evaluasi. Kognitif berarti persoalan yang menyangkut kemampuan untuk mengembangkan kemampuan rasional.

Di Indonesia isu tentang etika serta pelanggaran etis yang dilaksanakan para profesional telah sangat lama dijadikan perhatian yang sangat serius. Sugiantari \& Widanaputra (2016) memberi pernyataan bahwasannya meskipun seluruh profesi, termasuk profesi akuntansi mempunyai etika profesi tetapi etika itu dibentuk berdasarkan rasionalisme ekonomi saja, jadi wajar etika itu tak 
sanggup membuat manusia terhindar daripada hukuman moral serta etika agar berfokus pada keuntungan material. Seorang akuntan saat melakukan profesinya untuk memriksa telah diberi aturan sesuai Kode Etik Ikatan Indonesia (Revita, 2016).

Selain itu banyak praktisi dan akademisi akuntansi yang sepakat bahwa meningkatnya perilaku tidak etis adalah karena kurangnya perhatian terhadap etika dalam kurikulum pendidikan yang diterima mahasiswa saat ini. Hal ini akan menimbulkan rasa khawatir karena mahasiswa tidak peka terhadap masalah-masalah yang terjadi khususnya yang mencakup etika profesi yang nantinya mereka akan sulit beradaptasi jika mereka dihadapkan oleh situasi yang sama. Oleh sebab itu dapat sangatlah menarik untuk bisa tahu bagaimanakah reaksi yang diberikan oleh mahasiswa akuntansi tentang penting atau tidaknya memiliki prilaku etis yang melibatkan profesi akuntan dan nantinya mereka bisa jadikan pedoman dalam mejalankan suatu profesi akuntan nantinya, sehingga seorag mahasiswa bisa bersikap atau berprilaku yang sesuai dengan etika dan moral yang berlaku dalam menjalan suatu profesi sebagai akuntan dimasa mendatang.

Penelitian ini menganalisis mengenai pengaruh idealisme, tingkat pengetahuan dan love of moneypada persepsi mahasiswa akuntansi atas perilaku tidak etis akuntan. Penelitian ini penting dilakukan karena banyak fakta perilaku akuntan yang melanggar kode etik atau etika profesi akuntan, padahal sangat disarankan bagi semua profesi untuk berperilaku etis sesuai dengan nilai-nilai moral yang berlaku (Damayanthi, 2016).

Tujuan penelitian sesuai dengan latar belakang serta rumusan masalah yang telah dirumuskan, antara lain untuk memperoleh bukti empiris pengaruh idealisme pada persepsi etis mahasiswa akuntansi. Kemudian mendapatkanbukti empiris pengaruh tingkat pengetahuan pada persepsi etis mahasiswa akuntansi serta, memperoleh bukti empiris pengaruh love of money pada persepsi etis mahasiswa akuntansi Perkembangan selanjutnya, istilah kognitif menjadi popular sebagai salah satu psikologi manusia atau satu konsep umum yang berhubungan dengan masalah pemahaman, memperhatikan, memberikan, menyangka, pertimbangan, pengolahan informasi, pemecahan masalah, kesenjangan, membayangkan, memperkirakan, berfikir, dan keyakinan. Teori kognitif menekankan bagaimana proses atau upaya untuk mengoptimalkan kemampuan aspek rasional yang dimiliki oleh orang lain.

Riset yang dilakukan oleh Kohlberg pada tahun 1963 dan 1946 merupakan awal dikenalkanya teori perkembangan moral kognitif (Cognitive Moral Development) ke masyarakat. Menurut prospektif pengembangan moral kognitif, kapasitas moral individu menjadi lebih konpleks jika individu tersebut mendapatkan tambahan struktur moral kognitif pada setiap level pertumbuhan perkembangan moral. Terdapat tiga aspek yang membedakan pertimbangan etis dengan semua proses mental lainnya. Aspek kognisi (cognition) berdasarkan pada nilai-nilai dan bukan pada fakta yang tidak nyata, penilaian didasarkan atas beberapa isu yang melibatkan diri sendiri dan orang lain, dan penilaian disusun sekitar isu "seharusnya" daripada berdasarkan kesukaan biasa atau urutan pilihan (Colby and Kohlberg, 1987). Kohlberg menyempurnakan menjadi 
enam tahap yaitu semakin tinggi tahapan seseorang, maka semakin mengerti dan dapat membedakan perilaku etis dan tidak etis.

Pertumbuhan moral dipengaruhi oleh pertumbuhan eksternal dan pertumbuhan internal, pertumbuhan eksternal berasal dari rewards dan punishment yang diberikan, sedangkan pertumbuhan internal mengarah pada principle dan universal fairness (Kohlberg, 1969). Kohlberg mengidentifikasi tiga level perkembangan moral yang terdiri dari: tingkat prakonvensional, tingkat konvensional, tingkat pasca konvensional.

Tahapan dan tingkatan dari teori perkembangan moral kognitif adalah tingkat pre-conventional merupakan tingkat pertama yang berorientasi pada hukum dan ketaatan. Pada tahap ini konsekuensi fisik sebuah tindakan sapenuhnya ditentukan oleh kebaikan atau keburukan tindakan itu sendiri. Alasan anak untuk melakukan hal yang baik adalah untuk menghindari hukuman atau menghormati kekuatan otoritas fisik yang lebih besar. Selanjutnya pada tingkat kedua, berorientasi pada instrument dan relativitas. Pada tahap ini, tindakan yang benar adalah yang dapat berfungsi sebagi instrument untuk memuaskan kebutuhan anak itu sendiri atau kebutuhan mereka yang dipedulikan anak itu (Nugroho, 2008).

Tingkat conventional yang terdiri dari tingkat ketiga yang berorientasi pada kesesuaian interpersonal. Perilaku yang baik pada tahap konvensional awal ini adalah mememuhi ekspetasi mereka dari mana dia merasakan loyalitas, afeksi, dan kepercayaan seperti keluarga dan teman. Tindakan yang benar merupakan penyesuaian terhadap apa yang diharapkan secara umum dan perannya sebagai anak, saudara, teman yang baik, dan sebagainya. Melakukan apa yang baik dimotivasi oleh kebutuhan untuk dapat dilihat sebagai pelaku yang baik dalam pandangannya sendiri dan pandangan orang lain. Tingkat keempat berorientasi pada hukum dan keteraturan. Benar dan salah pada tahap konvensional yang lebih dewasa kini ditentukan oleh loyalitas terhadap negara atau masyarakat sekitarnya yang lebih besar. Seseorang sekarang dapat melihat orang lain sebagai bagian dari sistem social yang lebih besar yang mengdefinisikan peran dan kewajiban individu, dan dia dapat memisahkan norma-norma yang berasal dari site mini, dan relasi interpersonal dan motif-motif pribadi (Nugroho, 2008).

Tingkat post-conventional terdiri dari tingkat kelima yang berorientasi pada kontrak sosial. Seseorang menjadi sadar bahwa mempunyai hubungan beragam pandangan dan pendapat personal yang bertentangan dan menekankan cara yang adil untuk mencapai consensus dan kesepahaman, kontrak, dan proses matang. Dia percaya bahwa nilai dan norma bersifat relative, dan terlepas dari konsekuensi demokratis, semua hendaknya diberi toleransi. Tingkat ke-enam, berorientasi pada prinsip etis universal. Pada tahap terakhir ini, tindakan yang benar didefinisikan dalam pengertian prinsip moral yang dipilih karena komprehensivitas, universalitas, dan konsistensinya. Prinsip etis ini merupakan prinsip umum yang abstrak yang berkaitan dengan keadilan, kesejahteraan masyarakat, kesetaraan hak asasi manusia, rasa hormat terhadap martabat manusia individu, dan ide bahwa manusia bernilai pada dirinya dan harus diperlakukan demikian. Alasan seseorang untuk melakukan apa yang benar berdasarkan pada komitmen terhadap prinsip-prinsip moral tersebut dan dia 
melihatnya sebagai kriteria untuk mengevaluasi semua aturan dan tatanan moral yang lain (Nugroho, 2008).

Persepsi adalah bagaimana orang-orang melihat menginterprestasikan peristiwa, objek, setra manusia. Orang-orang bertindak atas dasar persepsi mereka dengan mengabaikan apakah persepsi itu mencerminkan kenyataan sebenarnya. Definisi persepsi yang formal adalah proses dimana seseorang memilih, berusaha, dan menginterprestasikan rangsangan ke dalam suatu gambaran yang terpadu dan penuh arti (Lubis, 2011:93).

Persepsi diartikan sebagai penerimaan atau pandangan seseorang melalui suatu proses yang didapat dari pengalaman dan pembelajaran sehingga seseorang mampu untuk memutuskan mengenai suatu hal. Kotler (2007:99) juga mendefinisikan persepsi sebagai suatu proses bagaimana seseorang menyeleksi, mengatur dan menginterprestasikan masukan-masukan informasi untuk menciptakan gambaran keseluruhan yang berarti.

Menurut Lubis (2011:93) mengatakan bahwa persepsi individu terhadap suatu objek yang sangat sama mungkin memiliki perbedaan yang disebabkan oleh 3 faktor, yaitu faktor pada pemersepsi, faktor dalam situasi dan faktor pada target. Faktor pada pemersepsi terdiri dari sikap, motif, kepentingan, pengalaman, dan pengharapan. Faktor dalam terdiri dari waktu, keadaan dan situasi sosial. Faktor pada target terdiri dari hal baru, gerakan, bunyi, ukuran, latar belakang dan kedekatan.

Menurut Dahlan (2008) etika secara lebih detail merupakan ilmu yang membahas moralitas manusia. Penyelidikan tingkah laku moral dapat diklarifikasikan sebagai berikut: etika deskriptif, etika normatif, dan mata etika bergerak seolah-olah pada taraf yang lebih tinggi dari pada prilaku etis, yaitu pada taraf "bahasa etis" atau bahasa yang digunakan di bidang moral. Penelitian Richmond (2001) Pemahaman tentang pengambilan keputusan etis dalam profesi akuntansi sangat penting karena fakta bahwa sebagian besar penilaian profesional bergantung pada keyakinan etis dan sikap individu.

Idealisme adalah suatu sikap yang menganggap bahwa tindakan yang tepat atau benar akan menimbulkan konsekuensi yang atau hasil yang diinginkan (Forsyth, 1992). Seorang individu yang idealis mempunyai prinsip bahwa merugikan individu lain adalah hal yang selalu dapat dihindari dan mereka tidak akan melakukan tindakan yang mengarah pada tindakan yang berkonsekuensi negatif. Pengetahuan adalah informasi atau maklumat yang diketahui atau disadari oleh seseorang. Dalam pengertian lain, pengetahuan adalah berbagai gejala yang ditemui dan diperoleh manusia melalui pengamatan akal (Wikipedia, 2018). Menurut Kholid (2012) tedapat 6 tingkat pengetahuan, yaitu: tahu (know), memahami (comprehension), aplikasi (aplication), analisis (analysis), sintesis (synthesis), evaluasi (evaluation)

Uang adalah alat tukar yang dapat diterima secara umum sehingga seseorang yang mempunyai uang dapat memenuhi kehidupannya, baik itu sandang, pangan dan papan. Penelitian Lea \& Webley (2006) dalam sebuah studinya mengungkapkan bahwa fungsi uang tidak hanya sebagai alat pembayaran tapi juga berfungsi sebagai narkoba, lebih lanjut mereka mengatakan bahwa uang berperan penting dalam memuaskan kebutuhan biologis dan psikologis. Dalam pengertian psikologis, uang dapat membuat 
seseorang ketagihan. Seperti narkoba, uang menjadi kuat, adiktif, dan menjadi motivator ulung dalam menimbulkan perasaan yang tidak pernah puas sehingga hal ini dapat menyebabkan perilaku yang buruk, misalnya gila kerja, berjudi, konsumsi yang berlebihan, dan berperilaku yang tidak etis (Tang \& Chen, 2008).

Keberadaan uang juga dinilai buruk bagi peneliti lainnya dan cenderung memberikan kontribusi negatif bagi pemiliknya. Tang (2007) dalam literaturnya mengatakan bahwa kehadiran uang meningkatkan sikap kemandirian di mana orang lebih memilih untuk bebas dari ketergantungan dan tanggungan terhadap orang lain, sehingga hal tersebut dapat mengurangi sifat saling membutuhkan satu sama lain, kemudian ia jarang meminta pertolongan dan jarang menolong orang lain. Orang yang menilai tinggi terhadap uang akan menjadi lebih privat, egois, terisolasi secara sosial, memiliki stress psikologis yang lebih tinggi, kebahagiaan yang lebih rendah, kesehatan mental dan fisik yang lebih buruk, kurang terbuka kepada orang lain, dan kurang peduli terhadap kemanusiaan dan spiritualitas dibandingkan mereka yang menilai rendah terhadap uang (Liu \& Tang, 2011).

Penelitian Thomas \& Tang (1992) mengenalkan skala terbaru yaitu Money Ethic Scale (MES), dalam skala ini uang diukur sebagai simbol prestasi dan kesuksesan, dengan enam faktor utama yang menunjukkan betapa berartinya uang bagi seseorang, Dari skala tersebut Tang beserta rekan-rekannya kemudian menyeleksi faktor-faktor yang ada di MES kemudian mengembangkannya sehingga muncullah Love of Money Scale (LOMS). Love of Money (LOM) merupakan bagian dari MES dan digunakan untuk mengukur perasaan subjektif individu terhadap uang, yang didalamnya terdapat empat faktor khusus yaitu : motivator, sukses (keberhasilan), pentingnya uang, dan kekayaan.

Penelitian Jwa.K et al. (2000) menemukan bahwa individu yang memiliki LOM yang tinggi lebih cepat untuk mencapai tujuan secara efektif dan efisien, ia juga menginginkan karir yang baik daripada orang yang kurang mencintai uang. Penelitian Liu \& Tang (2011) juga menemukan bahwa LOM berpengaruh positif terhadap optimisme keuangan personal, mereka berkesimpulan bahwa seseorang yang sangat mencintai uang selalu berpikir positif dan optimis bahwa keuangan pribadinya (seperti :gaji, pesangon, THR) akan selalu naik setiap tahunnya, oleh karena itu ia rela bekerja keras demi mencapai hal tersebut.

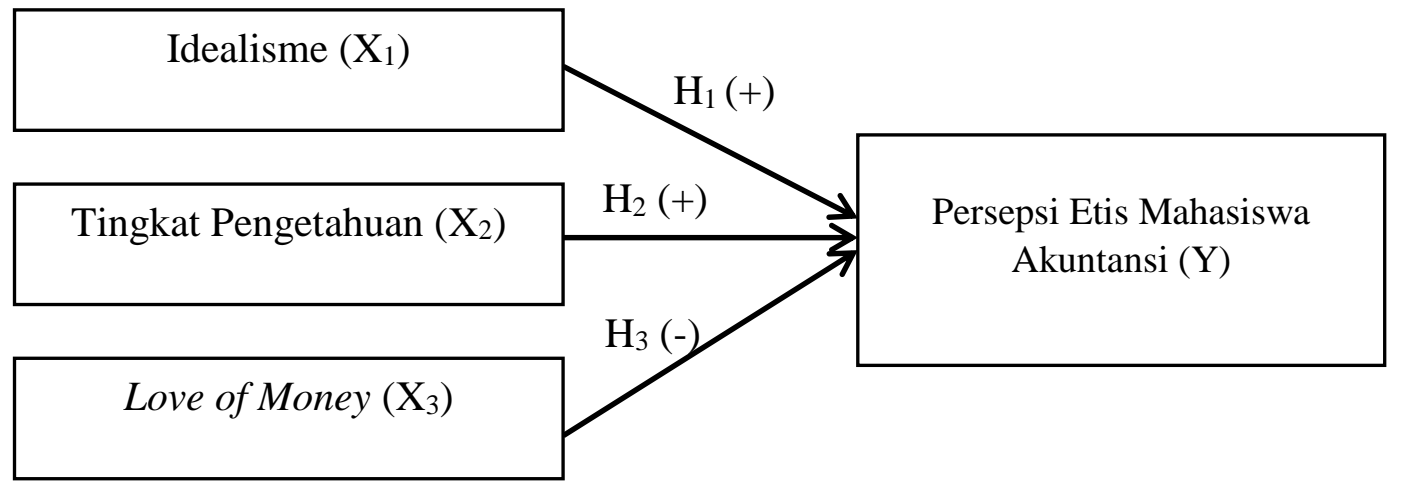

Sumber : Data Penelitian, 2019

Gambar 1. Kerangka Konseptual 
Penelitian yang dilakukan olehMilyawati (2017) menunjukkan bahwa tingkat idealisme berpengaruh pada opini mahasiswa terhadap perilaku etis akuntan. Hasil penelitian tersebut juga didukung oleh (Setiawan, 2013) memberi petunjuk bahwasannya idealisme memiliki pengaruh positif pada perilaku etis. Ini berarti bahwa hubungan idealisme searah dengan perilaku etis akuntan.

Dapat diartikan semakin tinggi tingkat idealisme yang dimiliki seseorang maka akan meningkatkan perilaku etisnya dalam melaksanakan tanggungjawab sebagai profesional akuntansi. Hal ini juga membuktikan bahwa seseorang memiliki idealisme tinggi dalam memegang prinsip etika maka seseorang akan senantiasa berperilaku etis. Berdasarkan uraian tersebut, maka peneliti merumuskan hipotesis sebagai berikut :

$\mathrm{H}_{1}$ : Idealisme berpengaruh positif pada persepsi etis mahasiswa.

Hasil penelitian Comunale et al. (2006) menunjukan bahwa tingkat pengetahuan mahasiswa akuntansi terhadap skandal dan profesi akuntansi akan berpengaruh signifikan terhadap pertimbangan etika mahasiswa akuntansi. Dalam memberikan tanggapan mengenai prinsip etika profesi akuntan, mahasiswa yang memiliki tingkat pengetahuan tinggi akan lebih bersikap bijaksana dan memberikan tanggapan baik terhadap perilaku etis dibandingkan dengan mahasiswa yang memiliki tingkat pengetahuan rendah yang akan memberikan tanggapan bahwa bersikap melanggar etika adalah suatu sikap yang tidak merugikan.Berdasarkan teori dan penelitian terdahulu, maka hipotesis yang akan diuji dalam penelitian ini adalah

$\mathrm{H}_{2}$ : Tingkat pengetahuan berpengaruh positif pada persepsi etis mahasiswa akuntansi.

Uang adalah aspek yang sangat penting dalam kehidupan sehari-hari. (Rubinstein \& Kroese, 2007) berpendapat bahwa di Amerika Serikat, kesuksesan diukur dengan uang dan pendapatan. Seorang manajer dalam bisnis menggunkan uang untuk menarik, mempertahankan, dan memotivasi karyawan (Elias, 2010).Sehingga hasilnya menimbulkan perilaku yang kontraproduktif (Tang \& Chiu, 2003). Penelitian Liu \& Tang(2011)menunjukkan bahwa seseorang dengan love of money yang rendah memiliki kepuasan kerja yang rendah. Hubungan antara perilaku cinta uang dengan persepsi etis telah diteliti lebih lanjut di beberapa negara. Elias(2010)menguji hubungan love of money apabila dikaitkan dengan persepsi etis menghasilkan hubungan yang negatif dan didukung oleh penelitian(Tang \& Chiu, 2003) yang memiliki pendapat bahwa etika uang seseorang memiliki dampak yang signifikan dan langsung pada perilaku yang tidak etis.

Love of money dan persepsi etis memiliki hubungan yang negatif. Hal ini disebabkan karena apabila seseorang memiliki kecintaan uang yang tinggi, maka ia akan berusaha utuk melakukan segala cara agar kebutuhannya terpenuhi walaupun tidak sesuai dengan etika. Berdasarkan hal tersebut, maka hipotesis yang akan diuji penelitian ini adalah :

$\mathrm{H}_{3}$ :Love of Money berpengaruh negatif pada persepsi etis mahasiwa akuntansi. 


\section{METODE PENELITIAN}

Desain penelitian ini menggunakan desain pendekatan asosiatif. Penelitian asosiatif adalah penelitian yang bertujuan untuk mengetahui hubungan antara dua variabel atau lebih.Lokasi penelitian akan dilakukan pada Fakultas Ekonomi dan Bisnis Universitas Udayana yakni pada Program Studi Akuntansi, yang meliputi program S1 Reguler Bukit angkatan 2015-2018. Objek pada riset berikut yaitu persepsi etis mahasiswa angkatan 2015 -2018 Program Studi Akuntansi regular bukit FEBUnud.Variabel terikat dalam penelitian ini adalah persepsi etis mahasiswa akuntansi (Y).Variabel bebas dalam penelitian ini adalah idealisme $\left(X_{1}\right)$, tingkat pengetahuan $\left(X_{2}\right)$, love of money $\left(X_{3}\right)$.Populasi pada penelitian ini berjumlah 142 orang.

Tabel 1. Mahasiawa Program Studi Akuntansi FEB UNUD Angkatan 2015-2018

\begin{tabular}{|c|c|c|c|}
\hline Tahun & Reguler(Bukit) & Non-Reguler(Denpasar) & Total \\
\hline 2015 & 142 & 133 & 275 \\
\hline 2016 & 167 & 135 & 302 \\
\hline 2017 & 150 & 138 & 288 \\
\hline 2018 & & & 250 \\
\hline
\end{tabular}

Sumber : Bagian Akademik FEB UNUD, 2019

Metode yang digunakan dalam pengambilan sampel pada penelitian ini adalah dengan metode nonprobability sampling yaitu sampel jenuh. Data kuantitatif dalam penelitian ini adalah jawaban kuesioner yang disebarkan yang kemudian diukur dengan skala likert. Pada kuesioner terdapat instrument pernyataan responden dalam pengisian kuesioner.

Sumber data primer pada penelitian ini adalah mahasiswa regular 2015 Program Studi Akuntansi Fakultas Ekonomi dan Bisnis Universitas Udayana. Data ini berupa kuesioner yang telah diisi oleh mahasiswa regular angkatan 2015 Program Studi Akuntansi Fakultas Ekonomi dan Bisnis Universitas Udayana yang telah menjadi responden pada penelitian ini.Data sekunder penelitian ini diperoleh dengan menggunakan metode tinjauan kepustakaan (library research) dan mengakses website maupun situs-situs.

Peneliti berusaha mengumpulkan data yang akurat dengan menggunakan kuesioner. Dalam penelitian kali ini peneliti menyebabkan kuesioner secara online kepada mahasiswa Program Studi Akuntansi regular bukit Fakultas Ekonomi dan Bisnis Universitas Udayana dengan menggunakan aplikasi Google Form.

Analisis regresi liniear berganda dilakukan untuk mengetahui hubungan antara lebih dari dua variabel, yaitu satu variabel sebagai variabel dependen dan beberapa variabel lain sebagai variabel independen. Dalam menguji hipotesis dikembangkan suatu persamaan untuk menyatakan hubungan anta variabel dependen, yaitu Y (Persepsi Etis Mahasiswa Akuntansi) dengan variabel independen, X ( Idealisme, Tingkat Pengetahuan dan Love of Money). Pengujian hipotesis dengan analisis regresi linier berganda diformulasikan sebagai berikut :

$$
Y=\alpha+\beta_{1} X_{1}+\beta_{2} X_{2}+\beta_{3} X_{3}+e
$$

Keterangan:

$$
\begin{aligned}
& Y=\text { Persepsi Etis Mahasiswa Akuntansi } \\
& a=\text { Konstanta } \\
& \text { X1 = Idealisme }
\end{aligned}
$$




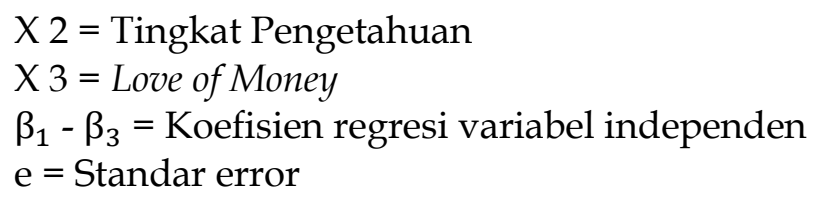

\section{HASIL DAN PEMBAHASAN}

Responden dari penelitian ini adalah mahasiswa reguler angkatan 2015 Program Studi Akuntansi Fakultas Ekonomi dan Bisnis Universitas Udayana. Kuesioner yang disebarkan kepada responden sebanyak 142 eksemplar dengan tingkat pengembalian responden 100 persen. Tingkat pengembalian yang dapat dianalisis sebesar 100 persen dengan rincian sebagai berikut.

Tabel 2. Data Pengiriman dan Pengembalian Kuesioner

\begin{tabular}{lc}
\hline \multicolumn{1}{c}{ Keterangan } & Jumlah \\
\hline Total Kuesioner yang disebar & 142 \\
Kuesioner yang tidak kembali & 0 \\
Kuesioner yang dikembalikan & 142 \\
Kuesioner yang tidak dapat digunakan & 0 \\
Kuesioner yang digunakan dalam analisis & 142 \\
Tingkat Pengembalian/Response Rate: & $100 \%$ \\
Tingkat Pengembalian yang digunakan / Usable Rate: & $100 \%$ \\
\hline
\end{tabular}

Sumber: Data Penelitian, 2019

Pada tabel 2 menunjukkan bahwa jumlah kuesioner yang disebarkan kepada responden sebanyak 142 kuesioner dan yang dikembalikan sebanyak 142 kuesioner.

Tabel 3. Karakteristik Responden

\begin{tabular}{llll}
\hline No & Keterangan & Jumlah & Persentase (\%) \\
\hline 1. & Jenis Kelamin: & & \\
& -Laki-laki & 45 & $31,69 \%$ \\
& -Perempuan & 97 & $68,31 \%$ \\
& Jumlah & 142 & $100 \%$ \\
\hline
\end{tabular}

Sumber : Data Penelitian, 2019

Berdasarkan Tabel 3 dapat dijelaskan bahwa profil jenis kelamin digunakan untuk mengetahui proporsi responden pria dan wanita. Tabel 3 menunjukkan bahwa responden yang berjenis kelamin pria sebanyak 45 orang $(31,69 \%)$ dan responden yang berjenis kelamin wanita 97 orang $(68,31 \%)$.

Tabel 4. Hasil Uji Statistik Deskriptif

\begin{tabular}{lcccc}
\hline \multicolumn{1}{c}{ Variabel } & $\begin{array}{c}\text { Nilai } \\
\text { Minumum }\end{array}$ & $\begin{array}{c}\text { Nilai } \\
\text { Maksimum }\end{array}$ & Mean & $\begin{array}{c}\text { Standar } \\
\text { Deviasi }\end{array}$ \\
\hline Idealisme $\left(\mathrm{X}_{1}\right)$ & 22,00 & 40,00 & 32,34 & 4,350 \\
Tingkat Pengetahuan $\left(\mathrm{X}_{2}\right)$ & 27,00 & 64,00 & 49,71 & 7,453 \\
Love of Money $\left(\mathrm{X}_{3}\right)$ & 16,00 & 38,00 & 31,27 & 4,944 \\
Persepsi Etis Mahasiswa & 8,00 & 32,00 & 17,08 & 4,082 \\
& & & &
\end{tabular}

$(\mathrm{Y})$

Sumber: Data Penelitian, 2019

Berdasarkan Tabel 4 dapat dijelaskan bahwa variabel Idealisme $\left(\mathrm{X}_{1}\right)$ memiliki nilai minimum sebesar 22,00, nilai maksimum 40,00, nilai rata-rata (mean) sebesar 32,34, dan standar deviasi sebesar 4,350. Hal ini menunjukkan terjadi perbedaan dari hasil jawaban responden mengenai idealisme terhadap 
nilai rata-ratanya sebesar 4,350.Variabel Tingkat Pengetahuan $\left(\mathrm{X}_{2}\right)$ memiliki nilai minimum sebesar 27,00, nilai maksimum 64,00, nilai rata-rata (mean) sebesar 49,71, dan standar deviasi sebesar 7,453. Hal ini menunjukkan terjadi perbedaan dari hasil jawaban responden mengenai tingkat pengetahuan terhadap nilai rataratanya sebesar 7,453 .

Variabel Love of Money $\left(\mathrm{X}_{3}\right)$ memiliki nilai minimum sebesar 16,00, nilai maksimum 38,00, nilai rata-rata (mean) sebesar 31,27, dan standar deviasi sebesar 4,944. Hal ini menunjukkan terjadi perbedaan dari hasil jawaban responden mengenai love of money terhadap nilai rata-ratanya sebesar 4,944.Variabel Persepsi Etis Mahasiswa Akuntansi $(Y)$ memiliki nilai minimum sebesar 8,00, nilai maksimum 32,00, nilai rata-rata (mean) sebesar 17,08, dan standar deviasi sebesar 4,082. Hal ini menunjukkan terjadi perbedaan dari hasil jawaban responden mengenai persepsi etis mahasiswa akuntansi terhadap nilai rataratanya sebesar 4,082 .

\section{Tabel 5. Hasil Uji Validitas}

\begin{tabular}{|c|c|c|c|}
\hline Variabel & Kode Instrumen & $\begin{array}{c}\text { Koefisien } \\
\text { Korelasi }\end{array}$ & Keterangan \\
\hline \multirow[t]{10}{*}{ Idealisme (X1) } & $\mathrm{X}_{1.1}$ & 0,740 & Valid \\
\hline & $X_{1} .2$ & 0,681 & Valid \\
\hline & $X_{1} .3$ & 0,804 & Valid \\
\hline & $X_{1} .4$ & 0,655 & Valid \\
\hline & $X_{1} .5$ & 0,586 & Valid \\
\hline & $x_{1} .6$ & 0,730 & Valid \\
\hline & $X_{1} .7$ & 0,791 & Valid \\
\hline & $X_{1} .8$ & 0,673 & Valid \\
\hline & $X_{1} .9$ & 0,821 & Valid \\
\hline & $X_{1.10}$ & 0,870 & Valid \\
\hline \multirow[t]{16}{*}{ Tingkat Pengetahuan (X2) } & $X_{2} .1$ & 0,680 & Valid \\
\hline & $X_{2} .2$ & 0,752 & Valid \\
\hline & $X_{2.3}$ & 0,778 & Valid \\
\hline & $\mathrm{X}_{2.4}$ & 0,481 & Valid \\
\hline & $X_{2} .5$ & 0,810 & Valid \\
\hline & $X_{2} .6$ & 0,888 & Valid \\
\hline & $X_{2.7}$ & 0,805 & Valid \\
\hline & $X_{2} .8$ & 0,707 & Valid \\
\hline & $\mathrm{X}_{2.9}$ & 0,785 & Valid \\
\hline & $X_{2.10}$ & 0,810 & Valid \\
\hline & $X_{2.11}$ & 0,883 & Valid \\
\hline & $X_{2} .12$ & 0,759 & Valid \\
\hline & $X_{2} .13$ & 0,855 & Valid \\
\hline & $X_{2.14}$ & 0,844 & Valid \\
\hline & $X_{2.15}$ & 0,878 & Valid \\
\hline & $X_{2.16}$ & 0,842 & Valid \\
\hline
\end{tabular}

Bersambung... 
Lanjutan Tabel. 5

\begin{tabular}{llll}
\hline Love of Money (X3) & $\mathrm{X}_{3.1}$ & 0,694 & Valid \\
& $\mathrm{X}_{3.2}$ & 0,829 & Valid \\
& $\mathrm{X}_{3.3}$ & 0,782 & Valid \\
& $\mathrm{X}_{3.4}$ & 0,801 & Valid \\
& $\mathrm{X}_{3.5}$ & 0,589 & Valid \\
& $\mathrm{X}_{3.6}$ & 0,589 & Valid \\
& $\mathrm{X}_{3.7}$ & 0,810 & Valid \\
& $\mathrm{X}_{3.8}$ & 0,555 & Valid \\
& $\mathrm{X}_{3.9}$ & 0,908 & Valid \\
& $\mathrm{X}_{3} .10$ & 0,747 & Valid \\
Persepsi Etis & $\mathrm{Y} .1$ & 0,824 & Valid \\
(Y) & $\mathrm{Y} .2$ & 0,733 & Valid \\
& $\mathrm{Y} .3$ & 0,850 & Valid \\
& $\mathrm{Y} .4$ & 0,793 & Valid \\
& $\mathrm{Y} .5$ & 0,707 & Valid \\
& $\mathrm{Y} .6$ & 0,777 & Valid \\
& $\mathrm{Y} .7$ & 0,699 & Valid \\
& $\mathrm{Y} .8$ & 0,745 & Valid \\
\hline
\end{tabular}

Sumber: Data Penelitian, 2019

Berdasarkan Tabel 5 dapat diketahui bahwa instrument pada tiap variabel dalam penelitian ini telah memenuhi syarat validitas, karena nilai koefisien korelasi setiap instrumen lebih besar dari 0,361.

Tabel 6. Hasil Uji Reliabilitas

\begin{tabular}{lcc}
\hline \multicolumn{1}{c}{ Variabel } & $\begin{array}{c}\text { Nilai Cronbach's } \\
\text { Alpha }\end{array}$ & Keterangan \\
\hline Idealisme $\left(\mathrm{X}_{1}\right)$ & 0,905 & Reliabel \\
Tingkat Pengetahuan $\left(\mathrm{X}_{2}\right)$ & 0,957 & Reliabel \\
Love of Money $\left(\mathrm{X}_{3}\right)$ & 0,917 & Reliabel \\
Persepsi Etis Mahasiswa Akuntansi & 0,905 & Reliabel \\
$(\mathrm{Y})$ & &
\end{tabular}

Sumber: Data Penelitian, 2019

Berdasarkan Tabel 6 dapat diketahui bahwa semua instrument penelitian dinyatakan reliabel karena masing-masing variabel memiliki nilai cronbach's alpha lebih besar dari 0,70.

Tabel 7. Hasil Uji Normalitas

\begin{tabular}{ccc}
\hline Model & $\mathrm{N}$ & Asymp.Sig.(2-tailed) \\
\hline Regresi & 142 & 0,730 \\
\hline
\end{tabular}

Sumber: Data Penelitian, 2019

Berdasarkan Tabel 7 dapat dilihat bahwa angka probabilitas atau Asymp. Sig (2-tailed) menunjukkan nilai 0,730 yakni lebih besar dari 0,05 yang artinya bahwa seluruh data dapat dikatakan berdistribusi normal.

Tabel 8. Hasil Uji Multikolinieritas

\begin{tabular}{lcc}
\hline \multicolumn{1}{c}{ Variabel } & \multicolumn{2}{c}{ Collinearity Statistic } \\
\cline { 2 - 3 } & Tolerance & VIF \\
\hline Idealisme $\left(\mathrm{X}_{1}\right)$ & 0,625 & 1,599 \\
Tingkat Pengetahuan $\left(\mathrm{X}_{2}\right)$ & 0,638 & 1,567 \\
Love of Money $\left(\mathrm{X}_{3}\right)$ & 0,967 & 1,034 \\
\hline
\end{tabular}

Sumber: Data Penelitian, 2019 
Berdasarkan Tabel 8 dapat dilihat bahwa hasil uji multikolinieritas menunjukkan bahwa variabel bebas memiliki nilai tolerance $<10$ persen dan nilai VIF> 10 dari masing-masing variabel bebas, maka dapat disimpulkan bahwa tidak ada multikolinieritas antar variabel bebas dalam model regresi.

Tabel 9. Hasil Uji Heteroskedastisitas

\begin{tabular}{lrc}
\hline \multicolumn{1}{c}{ Variabel } & Sig. & Keterangan \\
\hline Idealisme $\left(\mathrm{X}_{1}\right)$ & 0,549 & Bebas Heteroskedastisitas \\
Tingkat Pengetahuan $\left(\mathrm{X}_{2}\right)$ & 0,053 & Bebas Heteroskedastisitas \\
Love of Money $\left(\mathrm{X}_{3}\right)$ & 0,148 & Bebas Heteroskedastisitas \\
\hline
\end{tabular}

Sumber: Data Penelitian 2019

Berdasarkan Tabel 9 diketahui nilai signifikansi masing-masing variabel bebas lebih besar dari 0,05 sehingga dapat disimpulkan bahwa model regresi dalam penelitian ini bisa bebas dari gejala heteroskedastisitas.

Analisis regresi linear berganda dilakukan untuk mengetahui hubungan antar pengaruh idealisme, tingkat pengetahuan dan love of money pada persepsi etis mahasiswa akuntansi. Hasil analisis regresi linier berganda disajikan pada Tabel 10sebagai berikut.

Tabel 10. Hasil Analisis Regresi Linier Berganda

\begin{tabular}{|c|c|c|c|c|c|}
\hline \multirow[t]{2}{*}{ Model } & \multicolumn{2}{|c|}{ Unstandardized Coefficients } & Standardized & $\mathrm{T}$ & Sig \\
\hline & B & Std. Error & Beta & & \\
\hline (Constant) & 12,687 & 2,959 & & 4,287 & 0,000 \\
\hline Idealisme $\left(\mathrm{X}_{1}\right)$ & 0,181 & 0,080 & 0,192 & 2,258 & 0,026 \\
\hline $\begin{array}{l}\text { Tingkat Pengetahuan } \\
\left(\mathrm{X}_{2}\right)\end{array}$ & 0,171 & 0,046 & 0,312 & 3,697 & 0,000 \\
\hline Love of money $\left(\mathrm{X}_{3}\right)$ & $-0,318$ & 0,057 & $-0,385$ & $-5,615$ & 0,000 \\
\hline Adjusted ${ }^{2}$ & & & & & 0,360 \\
\hline $\mathrm{F}$ & & & 27,427 & & \\
\hline Sig. F & & & & & \\
\hline
\end{tabular}

Sumber: Data Penelitian, 2019

Berdasarkan tabel 10 diperoleh suatu persamaan regresi sebagai berikut:

$$
\mathrm{Y}=12,687+0,181 \mathrm{X}_{1}+0,171 \mathrm{X}_{2}-0,318 \mathrm{X}_{3}+\mathrm{e}
$$

Persamaan regresi tersebut dapat diinterprestasikan sebagai berikut.Nilai konstanta (a) sebesar 12,687 memiliki arti jika variabel idealisme $\left(X_{1}\right)$, tingkat pengetahuan $\left(\mathrm{X}_{2}\right)$, dan love of money $\left(\mathrm{X}_{3}\right)$ dinyatakan konstan, maka persepsi etis mahasiswa akuntansi $(\mathrm{Y})$ akanmeningkat sebesar 12,687.Nilai koefisien regresi dari variable idealisme $\left(X_{1}\right)$ bernilai 0,181 , berarti apabila variabel idealisme meningkat sebesar satu satuan, maka akan mengakibatkan peningkatan terhadap persepsi etis mahasiswa akuntansi sebesar 0,181 dengan asumsi variabel bebas lainnya konstan.

Nilai koefisien regresi dari variable tingkat pengetahuan $\left(X_{2}\right)$ bernilai 0,171, berarti apabila variabel tingkat pengetahuan meningkat sebesar satu satuan, maka akan mengakibatkan peningkatan terhadap persepsi etis mahasiswa akuntansi sebesar 0,171 dengan asumsi variabel bebas lainnya konstan.Nilai koefisien regresi dari variabellove of money bernilai $-0,318$, berarti apabila variable love of money meningkat sebesar satu satuan, maka akan mengakibatkan penurunan terhadap persepsi etis mahasiswa akuntansi sebesar 0,318 dengan asumsi variabel lainnya konstan. 
Berdasarkan Tabel 10 menunjukkan bahwa nilai Adjusted $R$ Square adalah 0,360 atau $36 \%$, ini artinya sebesar $36 \%$ variasi persepsi etis mahasiswa akuntansi dipengaruhi idealisme, tingkat pengetahuan dan love of money. Sedangkan sisanya sebesar $64 \%$ dijelaskan oleh faktor lain yang tidak dimasukkan dalam model penelitian ini.Berdasarkan Tabel 10 dapat dilihat bahwa nilai signifikansi $\mathrm{F}$ adalah sebesar 0,000 yang lebih kecil dari 5 persen. Hal ini berarti model penelitian layak (fit).

Berdasarkan Tabel 10 hasil pengujian pengaruh masing-masing variabel independen terhadap variabel dependen dapat dijabarkan sebagai berikut: pengaruh idealisme pada persepsi etis mahasiswa akuntansi.Berdasarkan tingkat signifikansi variabel idealisme sebesar 0,026 yang lebih kecil dari $a=0,05$, maka $\mathrm{H}_{1}$ diterima. Hal ini membuktikan bahwa idealisme berpengaruh positif dan signifikan pada persepsi etis mahasiswa akuntansi. Tingkat signifikansi variabel idealisme sebesar 0,026 artinya variabel idealisme berpengaruh signifikan sebesar $97,4 \%$ dikatakan bagus karena tingkat toleransi tidak signifikansi dibawah 0,005 atau $5 \%$.

Pengaruh tingkat pengetahuan pada persepsi etis mahasiswa akuntansi. Berdasarkan tingkat signifikansi variabel tingkat pengetahuansebesar 0,000 yang lebih kecil dari $\mathrm{a}=0,05$, maka $\mathrm{H}_{2}$ diterima. Hal ini membuktikan bahwa tingkat pengetahuan berpengaruh positif dan signifikan pada persepsi etis mahasiswa akuntansi. Tingkat signifikansi variabel tingkat pengetahuan sebesar 0,000 artinya variabel tingkat pengetahuan berpengaruh signifikan $100 \%$ terhadap persepsi etis mahasiswa akuntansi.

Pengaruh love of money pada persepsi etis mahasiswa akuntansi. Berdasarkan tingkat signifikansi variabel love of money sebesar, 0,000 yang lebih kecil dari $\mathrm{a}=0,05$, maka $\mathrm{H}_{3}$ diterima. Hal ini membuktikan bahwa love of money berpengaruh negatif dan signifikan pada persepsi etis mahasiswa akuntansi. Tingkat signifikansi variabel love of money sebesar 0,000 artinya variabel love of money berpengaruh signifikan $100 \%$ terhadap persepsi etis mahasiswa akuntansi.

Hasil analisis menunjukkan koefisisen regresi idealisme memiliki tanda positif. Hal ini menunjukkan semakin tinggi idealisme dalam memegang prinsip etika maka seseorang akan senantiasa berperilaku etis. Hasil ini mendukung hipotesis pertama $\left(\mathrm{H}_{1}\right)$ yang menyatakan bahwa idealisme berpengaruh positif pada persepsi etis mahasiswa akuntansi. Artinya semakin tinggi tingkat idealisme ynag dimiliki seseorang maka akan meningkat perilaku etisnya.

Penelitian Milyawati (2017) menunjukkan bahwa tingkat idealisme berpengaruh pada opini mahasiswa terhadap perilaku etis akuntan. Hasil penelitian tersebut juga didukung oleh (Setiawan, 2013) memberi petunjuk bahwasannya idealisme memiliki pengaruh positif pada perilaku etis. Ini berarti bahwa hubungan idealisme searah dengan perilaku etis akuntan.

Hasil analisis menunjukkan koefisien regresi tingkat pengetahuan memiliki tanda positif. Hal ini menunjukkan semakin tinggi tingkat pengetahuan yang dimiliki seseorang maka akan lebih etis dalam memberikan tanggapan maupun masukan. Hasil ini mendukung hipotesis kedua $\left(\mathrm{H}_{2}\right)$ yaitu tingkat pengetahuan berpengaruh positif pada persepsi etis mahasiswa akuntansi. Artinya dalam memberikan tanggapan mengenai prinsip etika profesi akuntan, mahasiswa yang memiliki tingkat pengetahuan tinggi akan lebih bersikap bijaksana dan 
memberikan tanggapan baik terhadap perilaku etis dibandingkan dengan mahasiswa yang memiliki tingkat pengetahuan rendah.

Hasil ini mendukung hipotesis ketiga $\left(\mathrm{H}_{3}\right)$ yang menyatakan bahwa love of money berpengaruh negatif pada persepsi etis mahasiswa akuntansi.Hasil analisis menunjukkan koefisien regresi love of money memiliki tanda negatif. Hal ini menunjukkan semakin tinggi love of money seseorang maka ia akan berusaha untuk melalukan segala cara agar kebutuhannya terpenuhi walaupun tidak sesuai dengan etika.

Uang adalah aspek yang sangat penting dalam kehidupan sehari-hari. Rubinstein \& Kroese (2007) berpendapat bahwa di Amerika Serikat, kesuksesan diukur dengan uang dan pendapatan. Elias (2010) menguji hubungan love of money apabila dikaitkan dengan persepsi etis menghasilkan hubungan yang negatif dan didukung oleh penelitian (Tang \& Chiu, 2003) yang memiliki pendapat bahwa etika uang seseorang memiliki dampak yang signifikan dan langsung pada perilaku yang tidak etis. Love of Money merupakan perilaku kecintaan seseorang terhadap uang dalam bentuk material, bisa juga diwujudkan dalam bentuk benda atau barang berwujud lainnya yang diperoleh dengan menggunakan uang yang mereka miliki.

\section{SIMPULAN}

Berdasarkan hasil analisis dan pembahasan, maka dapat disimpulkan seperti berikut: semakin tinggi tingkat idealisme yang dimiliki seseorang maka akan meningkatkan perilaku etisnya dalam melaksanakan tanggungjawab sebagai profesional akuntansi. Hal ini juga membuktikan bahwa seseorang memiliki idealisme tinggi dalam memegang prinsip etika maka seseorang akan senantiasa berperilaku etis.Semakin tinggi tingkat pengetahuan seseorang maka semakin bijak dalam berperilaku etis. Dalam memberikan tanggapan mengenai prinsip etika profesi akuntan, mahasiswa yang memiliki tingkat pengetahuan tinggi akan lebih bersikap bijaksana dan memberikan tanggapan baik terhadap perilaku etis dibandingkan dengan mahasiswa yang memiliki tingkat pengetahuan rendah yang akan memberikan tanggapan bahwa bersikap melanggar etika adalah suatu sikap yang tidak merugikan.Love of money dan persepsi etis memiliki hubungan yang negatif. Hal ini disebabkan karena apabila seseorang memiliki kecintaan uang yang tinggi, maka ia akan berusaha utuk melakukan segala cara agar kebutuhannya terpenuhi walaupun tidak sesuai dengan etika.

Berdasarkan kesimpulan, maka dapat disampaikan beberapa saran, yaitu: idealisme merupakan suatu tindakan yang baik atau buruk akan membawa konsekuensinya sendiri. Hasil jawaban responden dalam kuesioner no. 7 yaitu " tindakan bermoral adalah tindakan yang hampir sesuai dengan tindakan sempurna" dimana banyak jawaban tidak setuju dan sangat tidak setuju terhadap pernyataan tersebut. Jadi masih kurangnya sikap idealisme responden dalam menyikapi penyataan tersebut.Tingkat Pengetahuan merupakan informasi atau maklumat yang diketahui atau disadari oleh seseorang. Hasil jawaban responden dalam kuesioner no. 14 yaitu " seorang akuntan tidak harus mematuhi standar yang dikeluarkan oleh IAI.Love of Money yaitu suatu sikap seseorang yang cinta terhadap uang. Hasil jawaban responden dalam kuesioner 
no. 7 "uang adalah akar dari kejahatan" dimana banyak responden yang tidak setuju dalam pernyataan tersebut, tetapi berkaitan dengan pengertian love of money tentang kecintaan terhadap uang, dimana seseorang akan rela melakukan segala cara untuk memenuhi kebutuhanya dengan menggunakan uang yang mereka miliki walaupun tindakan yang kurang baik sekalipun atau suatu tindak kejahatan.

\section{REFERENSI}

Colby, A. and Kohlberg, L. (1987). The Measurement of Moral Judgement. New York: Cambridge University Press.Vol 32.6, pp: 388-397.

Comunale, C. L., Sexton, T. R., \& Gara, S. C. (2006). Professional ethical crises: A case study of accounting majors. Managerial Auditing Journal. Vol 21.6, pp: 636-656.

Dahlan, A. (2008). Ilmu, Etika, dan Agama: Representasi Ilmu Ekonomi Islam Ahmad. Ibda', 6(1), 71-91.

Damayanthi, P. D. A. (2016). Pengaruh Idealisme, Relativisme, Pengetahuan, Gender dan Umur pada Perilaku Tidak Etis Akuntan. E-Jurnal Akuntansi Universitas Udayana, 15(1), 1-16.

Detik Finance. (2007). Depkeu Bekukan Izin Akuntan Publik Ketut Gunarsa. Retrieved January 20, 2019, from https://finance.detik.com/beritaekonomi-bisnis/d-795012/depkeu-bekukan-izin-akuntan-publik-ketutgunarsa

Diana, A. R. (2017). Pengaruh Pengetahuan Etika, Religius Dan Love of Money Terhadap Persepsi Etis Mahasiswa Akuntansi. Skripsi Sarjana Jurusan Akuntansi Fakultas EkonomiUniversitas Negeri Yogyakarta.

Elias, R. Z. (2010). The Relationship Between Accounting Student Love of Money and Their Ethical Perception. Managerial Auditing Journal, 25(3), 269-281.

Forsyth, D. (1980). A Taxonomy of Ethical Ideologies. Journal of Personality and Social Psychology, 39, 175-184.

Forsyth, D. (1992). Judging the Morality of Business Practices: the Influence of Personal Moral Philosophies. Journal of Business Ethics, 11, 416-470.

Gadjali, R., \& Birton, M. N. U. R. (2014). Analisis pengaruh jenis kelamin dan masa kerja terhadap persepsi etis akuntan manajemen dengan. Simposium Nasional Akuntansi 17 Mataram, Lombok.

Jwa K, Kim, David Shin Hsiung, Tang, \& Thomas Li Ping, Tang. (2000). Does attitude toward money moderate the relationship between intrinsic job satisfaction and voluntary turnover? Human Relations. Vol 53.2, pp: 213-245.

Kholid, A. (2012). Promosi Kesehatan dengan pendekatan teori perilaku, media, dan aplikasinya. Jakarta: Raja Grafindo Persada.

Kohlberg, L. (1969). Moral stages and moralization. In Stage and sequence: The cognitive-developmental approach to socialization. Handbook of socialization theory, pp:347-480.

Kotler, P. (2007). Philip Kotler. In Guide to Management Ideas \& Gurus. Vol 36.4, pp: 60-61.

Kurniawan, P. I. (2017). Pengaruh Love Of Money dan Machiavellian Terhadap Persepsi Etis Mahasiswa Akuntansi.Skripsi Sarjana Akuntansi Fakultas Ekonomi dan Bisnis Udayana, Bali. 
Lea, S. E. G., \& Webley, P. (2006). Money as tool, money as drug: The biological psychology of a strong incentive. Behavioral and Brain Sciences. Cambridge Universitas Press.

Liu, B. C., \& Tang, T. L. P. (2011). Does the Love of Money Moderate the Relationship between Public Service Motivation and Job Satisfaction? The Case of Chinese Professionals in the Public Sector. Public Administration Review. Vol 71.5, pp: 718-727.

Lubis, A. I. (2011). Akuntansi Keprilakuan. Jakarta: Salemba Empat.

Luna-Arocas, R., \& Tang, T. L. P. (2004). The love of money, satisfaction, and the protestant work ethic: Money profiles among university professors in the U.S.A. and Spain. Journal of Business Ethics. Vol 50.4, pp:329-354.

Milyawati, A. U. dan D. D. (2017). Pengaruh Idealisme, Relativisme, Love of Money, Gender dan Tingkat Pengetahuan Akuntansi terhadap Persepsi Mahasiswa Akuntansi atas Perilaku Tidak Etis Akuntan. Skripsi Universitas Maritim Raja Ali Haji.

Nugroho, B. (2008). Faktor-Faktor yang Mempengaruhi Penilaian Mahasiswa Akuntansi atas Tindakan Auditor dan Coorporate Manager dalam Skandal Keuangan serta Tingkat Ketertarikan Belajar dan Berkarier di Bidang Akuntansi. Skripsi Sarjana Akuntansi Fakultas Ekonomi Universitas Diponegoro.

Revita Mardawati. (2016). Pengaruh Orientasi Etis, Gender, Dan Pengetahuan Etika Terhadap Persepsi Mahasiswa Akuntansi Atas Perilaku Tidak Etis Akuntan. Skripsi Sarjana Akuntansi Fakultas Ekonomi Universitas Negeri Yogyakarta.

Richmond, K. A. (2001). Ethical reasoning, Machiavellian behavior, and gender: The impact on accounting students' ethical decision making. Dissertation submitted to the Faculty of the Virginia Polytechnic Institute and State University. 20 April 2001.

Rubinstein, R. Y., \& Kroese, D. P. (2007). Simulation and the Monte Carlo Method: Second Edition. Simulation and the Monte Carlo Method: Second Edition. pp :1335.

Setiawan, A. . (2013). Pengaruh Budaya Etis, Orientasi Etis terhadap Perilaku Etis. SkripsiSTIE Musi Palembang.

Smith, B. (2009). Ethical Ideology And Cultural Orientation: Understanding The Individualized Ethical Inclinations Of Marketing Students. American Journal of Business Education. Vol 2.8, pp:27.

Sugiantari, N. K., \& A.A.G.P.Widanaputra. (2016). Pengaruh Idealisme, Relativisme, Dan Love of Money Pada Persepsi Mahasiswa Akuntansi Tentang Krisis Etika Akuntan. E-Journal Akuntansi Universitas Udayana.

Tang, T. L. (1992). The meaning of money revisited. Journal of Organizational. Vol 13.2, pp: 197-202.

Tang, T. L. P. (2007). Income and quality of life: Does the love of money make a difference? Journal of Business Ethics. Vol 72.4, pp: 375-393.

Tang, T. L. P., \& Chen, Y. J. (2008). Intelligence vs. wisdom: The love of money, machiavellianism, and unethical behavior across college major and gender. Journal of Business Ethics. Vol 82.1, pp:1-26.

Tang, T. L. P., \& Chiu, R. K. (2003). Income, Money Ethic, Pay Satisfaction, Commitment, and Unethical Behavior: Is the Love of Money the Root of Evil 
for Hong Kong Employees? Journal of Business Ethics. Vol 46.1, pp:13-30.

Wikipedia. (n.d.). Pengetahuan. Retrieved Desember 5, 2018, from https://id.wikipedia.org/wiki/Pengetahuan 